\title{
Linguistics of Augmentative and Alternative Communication in the Process of Diagnosis of Speech Inability and Speech Non-Occurrence
}

Lingwistyka komunikacji alternatywnej i wspomagającej w procesie diagnozy niemowności oraz niemówienia

Keywords: linguistics of augmentative and alternative communication, applied linguistics, speech inability, speech nonoccurrence

Słowa kluczowe: lingwistyka komunikacji alternatywnej i wspomagającej, lingwistyka stosowana, niemowność, niemówienie

\section{Introduction}

Analysing the phenomenon of broadly understood situation of lack of speech, which was not defined at the beginning of the paper on purpose, continued to be the domain not so much of logopaedics as of practical, diagnostic and therapeutic activity referred to as Augmentative and Alternative Communication (AAC) for many years. Nowadays, it is assumed that AAC is a set of clinical and educational activities attempting to research and, if necessary, compensate transitory or permanent difficulties, limited participation in communication of persons with serious disorders in production and comprehension of the language both in its spoken and written aspect [cf. Beukelman, Mirenda, 2013, p. 4]. In their study which is considered classic today, Stephen von Tetzchner and Harald Martinsen propose the following distinction, having terminologies land practical consequences: 1) alternative communication - it finds its application when a person communicates directly - face to face

\footnotetext{
* Pedagogical University of Krakow, Institute of Polish Philology IFP, 2 Podchorążych street, 30-084 Kraków, e-mail: miroslaw.michalik@up.krakow.pl, ORCID: https://orcid.org/0000-0002-9260-3014.
} 
- in a way different than using speech. Manual or graphic signs, Morse code or writing are examples of alternative forms of communication for people with no ability of speaking; 2) augmentative communication denotes supplementary or aided communication. The word 'augmentative' stresses the fact that intervention with the use of alternative communication means has a twofold purpose: augment and supplement speech and provide a substitute way of communicating when an individual does not begin to speak [Tetzchner, Martinsen, 2002, p. 7]. In this typology, but also in the Polish therapeutic and terminological tradition, priority is given to alternative communication being a kind of speech substitute (alternative communications), followed by augmentative activities and solutions which support and stimulate speech (augmentative communications) [cf. Michalik, 2018]. This order will be reflected in the subsequent part of the paper.

Apart from AAC therapists the subject of lack of speech was also discussed by speech therapists as well as psychologists, psychiatrists, phoniatrists, neurologists and special education teachers [Michalik, 2018, pp. 41-109]. One common feature of these attempts was the use of inductive reasoning which is based on experience, an individual fact, practical knowledge, with the use of which general sentences are made probable [Bobrowski, 1998]. If it is assumed that "induction, as Ireneusz Bobrowski notices, is always a kind of reasoning which makes arguments more probable (not infallible), since the number of detailed premises in the reasoning is always limited (even if their number was very large)" [Bobrowski, 1998, p. 22], this way of reaching the phenomenon of lack of speech must be ex definitione deficient, incomplete and fragmentary. So as to obtain a different, perhaps complete, map of the state of lack of speech, it is necessary to resort to another way of thinking oppositional to induction, namely deduction in which "on the basis of deductive reasoning one proceeds from more general statements to more and more detailed ones, extending the deductive system" [Bobrowski, 1998, p. 25]. The linguistics of augmentative and alternative communication is a result of such axiomatic reasoning on lack of speech in which statements are justified by means of evidence from previous statements considered to be true (premises).

\section{Linguistics of augmentative and alternative communication: in the direction of distinguishing a sub-discipline of applied linguistics}

Linguistics of augmentative and alternative communication may be defined, referring to terminological findings of educational linguistics [Rittel, 1994], as linguistics with strong methodological foundations using and developing a set of theoretically ordered terms (parametres) which may/should be used in the description of acquisition of the ability of speaking by individuals. The main parametre of such a linguistic sub-discipline is linguistic competence whose main components include: language 
competence (grammatical and lexical), communicative competence (sociolinguistic, communicative, pragmatic) and cultural (linguistic and cultural) often referred to as cognitive competence [cf. Rittel, 1994] ${ }^{1}$. The secondary parametres of linguistics of augmentative and alternative communication deeply rooted in the theory of logopaedics as a science on biological conditionings of speech development and speech disorders include speech inability and speech non-occurrence, which are discussed later in the article [cf. Przebinda, Michalik, 2020].

Speech inability, being an anonym of the noun phrase speech ability, is a condition accompanying a human being in which there is no system of activities performed with the use of language in order to get to know the reality and pass on its interpretation to other participants in social life [cf. Michalik, 2018, p. 43; Michalik, Przebinda, 2020]. This definition refers to, on the one hand, the logopaedics tradition, namely the definition of speech by Stanisław Grabias [2015] and, on the other, lexicographic findings. In addition, it makes references to etymology in Polish [cf. Michalik, 2018, pp. 45-49]2.

Speech non-occurrence, in turn, is defined in anatomical relation to speaking, which is understood after Renata Grzegorczykowa as an individual act of transmission and reception in which the sender selects appropriate vocabulary and grammatical structures from the language code in order to give the recipient some information, activates the speech organs to realise the form of selected language units, as a result of which sound waves are sent out to the ear of the recipient whose reception organs receive the sound and interpret it mentally [Grzegorczykowa, 2007, p. 14]. Making a reference to this definition, another definition of speech non-occurrence stemming from linguistics may be proposed: the sender, (not?) ${ }^{3}$ wishing to give the recipient certain information, does not choose the appropriate vocabulary and grammatical structures from the linguistic code, does not activate the speech organs which are supposed to realise the form of selected language elements, as a result of which no acoustic waves are sent to the ear of the recipient whose reception organs do not receive the sound and interpret it mentally [cf. Grzegorczykowa, 2007; Michalik, 2018,

1 The term includes three levels: the basic one, comprising the three components-competences distinguished above, and the two superimposed ones, i.e. the over-competence and the sub-competence [Rittel, Rittel, 2015]. In addition, linguistic competence may be described relying on the scale of its evaluation. The units of this scale include: transitional, approximate and target competence. The first one, transitional competence, may be may be preceded in the process of speech acquisition by the level of sub-competence, characterized primarily by the distorted discourse, whereas the last one, the target competence, evolves into second-level language creation, i.e. over-competence in certain situations [Rittel, 1994]. 2 Referring to earlier publications, one can only signalize that the adjective 'mute' in Polish language dictionaries is defined in two ways: 1) "unable to speak, speechless" (dictionaries: Linde, the so called Warsaw-based and edited by Witold Doroszewski, 2) "without the gift of speech" (Doroszewski's dictionary). The first meaning corresponds to our understanding of the term [cf. Michalik, 2018].

3 It is often impossible to decide whether the non-speaking person wants (does not want) to convey the information to the recipient. 
pp. 43-44]. Taking this distinction into consideration, it is possible to identify two groups of persons within linguistics of augmentative and alternative communication and the therapeutic practice alone: 1) affected by speech inability (mute), or not having speech (in the meaning of langage) and consequently not undertaking a set of activities which the speaking person performs with the use of the language, not getting to know the reality on the level of verbose persons and not conveying their interpretation to other participants of social life; 2) non-speaking, i.e. having a language system (in the meaning of langue) but not conveying any information to the recipient, not choosing the adequate vocabulary and grammatical structures from the linguistic code (langue), not using their speech organs to realise the form of selected language units, as a result of which not sending any acoustic waves to the ear of the recipient, whose reception organs do not receive the sound and its mental interpretation [cf. Michalik, 2018, pp. 50-51; Przebinda, Michalik, 2020].

Recalling at this point the neo-positivist model of the structure of science, it may be argued that linguistics of augmentative and alternative communication has:

- The subject of research and the defined level of metascientific reflection. The subject of linguistics of augmentative and alternative communication is speech and communication of mute and non-speaking persons, where the speech of mute persons is defined in accordance with the definition of speech by Grabias [2015, p. 19] as a set of activities which is performed by a mute person, with the passive role of the natural language and active participation of AAC systems, in order to get to know the reality and pass on its interpretation to other participants in social life. This linguistics also has a certain level of metascientific reflection: its methodology, belonging to the order of metascience, performs the following functions: critical, structural, cognitive, gnoseological, praxis and verification; it also has a dynamic and functional dimension [Michalik, 2018, p. 120].

- Hierarchical structure of aims: primary research enriches and orders theoretical knowledge; applied research develops the results of primary research for practical purposes; implementation research builds techniques to achieve intended practical aims.

The primary research concerns: speech non-occurrence and speech inability situated within a unified, homogeneous, complete, universal theory of linguistics of alternative communication with linguistic competence as the main parametre; the theory of linguistic competence adopted for the purposes of speech and communication of mute persons and communication of non-speaking persons.

\section{Applied research is focused within:}

- the theory of linguistic competence, for instance, on grammatical competence of the first degree, the power of sub-competence and transient competen$\mathrm{ce}$, the power of the grammatical plane, the language system realising the 
possibility of using the AAC code, the internal I-language, the I-grammar, syntaxation, connotation, accommodation, concrete and abstract vocabulary with mastering the centre of the field, the mental dictionary, anchring verbs in the mental dictionary, minimum lexical resource of the language, the basic range of necessary words, the basic range of extended vocabulary, intercode translation and subordination of communicativeness;

- theory of communicative competence on: the universal rules of communicative interaction, components of competencies, i.e.: the system potential, feasibility, occurrence, appropriateness; an utterance as a communication unit, a communication event; the ability to use different semiotic systems; social communication networks, linguistic situation, domains (classes of situations); communicativeness/uncommunicativeness; the code conglomerate (a specialised AAC code vs. the code of general language); illocution, perlocution; assertives, directives and expressives; directs acts of speech; presupposition types; principles and maxims of conversation; the restricted code; extra-linguistic communication behaviour; pre-intentional/intentional communication; communication skills: social, situational, pragmatic competence; common attention;

- the theory of cognitive competence, for instance, on: general knowledge, knowledge on phenomena of the reality, context, experience, world exploration and interpretation, passing on interpretation to other people, cultural rules, values.

Building techniques aimed at realising indended practical aims, implementation research of linguistics of augmentative and alternative communication primarily serves to interiorise speech in mute persons understood as a set of activities performed by a mute person while getting to know the world and passing on knowledge about themselves and the world to other participants of social life as well as its diagnosis. AAC systems, methods and techniques are used for this purpose.

Procedures and tools of research proceedings (also practical ones) [cf. Grabias, 2019].

\section{Diagnosis of the degree of speech proficiency by mute persons as an example of a procedure of research proceeding within linguistics of augmentative and alternative communication}

In the case of applied linguistics, which is linguistics of augmentative and alternative communication, the procedures of research and practical proceeding are often identical as they deal with capturing the importance of elements and relationship between them, filling the continuum oscillating between research facts (sensory 
incidents recognised by the researcher's mind interpreted against the background of previous knowledge, adjusted to the message used in corrective action [cf. Grabias, 2019, p. 294]) and individual facts (the concrete individual affected by speech inability or speech non-occurrence). The following are the most important areas of linguistic competence (the main parametre connected with the research fact) of a mute child (an auxiliary parametre connected with the scientific individual fact), which should be diagnosed, described and explained in a situation of lack of speech.

- Within the framework of linguistic (grammatical/lexical) competence, the following are assessed: a) the lexical layer, including: the degree of assimilating both passive and active vocabulary with particular focus on grammatical variety (parts of speech) and meaning diversity (core and additional vocabulary); b) the syntactic layer, including: structural complexity of the utterance composed of symbols or gestures, the order of words (notions) in the utterance; c) morphology, including: the understanding of basic grammatical categories, especially those which play an important role in conveying the meaning accurately, as well as assessment of the use of graphic indicator of these categories; d) phonological awareness and grapheme perception: examination of the phonological awareness of the AAC user should be carried out using images in which the mute person may indicate the answer, or with the use of some tool (a prosthesis) to communicate. It is important to make sure that the pictures are presented only after the child signals that it knows the answer. This is supposed to prevent a situation when the child guesses the answer and becoming prompted e.g. by the first sound in syllable and phoneme synthesis [cf. Przebinda, Michalik, 2020] ${ }^{4}$.

- Within the framework of the communicative competence, which in AAC linguistics primarily consists in the ability to pursue different objectives in communication acts assessment includes:

- the pragmatic competence, including: acts of speech such as asking for a person, thing, activity, permission, break, food, possibility of using the restroom, conversation, continuation of stopped activity, finishing the activity; commenting, expressing one's own negative or positive attitude to people, things, activities, phenomena, animals; the ability of justifying the above preferences and aversions; giving names to people, things, phenomena, activities, characteristics, way, place, time; confirming; denying and declining; asking about people, activities, places, objects, time, way, characteristics; saying hallo and good bye, greeting; thanking; inviting; apologizing; borrowing

4 Mute/non-speaking children have serious disorders of phonological awareness due to their lack of experience in phoneme realization which requires the use of special techniques. The most useful approach here is the glottodidactic approach elaborated by Bronisław Rocławski [2010]. This approach divides the skills of auditory synthesis and analysis into very small steps and establishes their order of priority in terms of the degree of difficulty [Rocławska-Daniluk, 2017, pp. 46-52]. 
and lending; exchanging things; initiating a conversation; signalling a change in the topic of conversation; expressing lack of understanding; volunteering; explaining the reason and purpose; entering into agreements; solving conflicts and misunderstandings; joking; planning and expressing intentions; boasting; wishing; building definitions; giving instructions; relating a sequence of events; expressing emotional states; expressing sensations from the body, especially discomfort; defining intellectual states; the vast majority of them fit into the Searl class of assertives, directives and expressives [cf. Michalik, Przebinda, 2018, pp. 170-172; Przebinda, Michalik, 2020];

- situational competence - it assesses the use of the communication tool (a speech prosthesis) in order to realise these pragmatic skills, firstly in routine situations during the day, and then in situations which are cyclical and, finally, in new situations; it is also necessary to check the ability to have a conversation on a topic connected with the situational context as well as the ability to talk about a subject which is distant in time or/and space [Michalik, Przebinda, 2018, pp. 170-172; Przebinda, Michalik, 2020];

- social competence - assessment refers to the ability to build a common field of attention and alternate activity (functional dialogue) [Grycman, 2014; 2015 ] as well as the ability to communicate with a growing group of recipients [Michalik, Przebinda, 2018, pp. 172-173; Przebinda, Michalik, 2020].

- Within the framework of cognitive competence, the following skills and competences are assessed: maintaining a common field of attention in the course of the child's interactive activity; making choices; announcing, including: announcing the next step, the following activities during routine operations; planning activities and events; reasoning; problem solving, including: asking for help, giving guidance, asking for information, considering alternative solutions; categorising, including: sorting everyday objects into two categories, sorting objects during everyday activities, e.g. cleaning, matching objects according to their function, giving a superior category, establishing own categories and justifying them; perceiving similarities and differences, including: comparing, using vocabulary such as: the same, different, similar; awareness of thoughts and feelings, including: naming one's own feelings and emotions, the feelings and emotions of others, the ability to "manage" them, responding correctly to the feelings of others; acquiring, segregating, evaluating information; perceiving illogicality and lack of sense of someone's behaviour or words; awareness of one's own thoughts [Michalik, Przebinda, 2018, pp. 173-175; Przebinda, Michalik, 2020]. 


\section{Summary}

One may question the status of linguistics of augmentative and alternative communication as a separate sub-discipline of applied linguistics. On the one hand, this may be done by therapists-practitioners who - departing from description, interpretation and therapy of individual facts - end their reflection on them, referring to the postulate of individualization of the therapeutic process and the case study as a research method. Reservations may be also expressed by theoreticians of applied linguistics who may argue that there is no use in distinguishing a sub-discipline whose subjects and the subject matter often enter into the research area of logopaedics, educational linguistics or special needs education. And these opponents may be said to be right in a way. Considering the fact, however, that linguistics of augmentative and alternative communication has a specific subject of research (all persons dealing with speech inability and speech non-occurrence), its own subject of research (speech and communication of mute persons and communication of non-speaking persons) as well as the adequate level of scientific reflection whose crowning is its own metodology, its pursuit of autonomy is not unfounded [cf. Grucza, 1983].

\section{References}

Beukelman D.R., Mirenda P., 2013, Augmentative \& Alternative Communication. Supporting Children and Adults with Complex Communication Needs, Baltimore: Paul H. Brookes Publishing Co.

Bobrowski I., 1998, Zaproszenie do językoznawstwa, Kraków: Wydawnictwo Instytutu Języka Polskiego Polskiej Akademii Nauk.

Grabias S., 2015, Postępowanie logopedyczne. Standardy terapii, [in:] S. Grabias, J. Panasiuk, T. Woźniak (eds.), Logopedia. Standardy postępowania logopedycznego, Lublin: Wydawnictwo Uniwersytetu Marii Curie-Skłodowskiej, pp. 13-35.

Grabias S., 2019, Język w zachowaniach społecznych. Podstawy socjolingwistyki i logopedii, Lublin: Wydawnictwo Uniwersytetu Marii Curie-Skłodowskiej.

Grucza F., 1983, Zagadnienia metalingwistyki. Lingwistyka - jej przedmiot, lingwistyka stosowana, Warszawa: Państwowe Wydawnictwo Naukowe.

Grycman M., 2014, Porozumiewanie się z dziećmi ze złożonymi zaburzeniami komunikacji. Poradnik nie tylko dla rodziców, Kwidzyn: Wydawnictwo Rehabilitacyjne Centrum Rozwoju Porozumiewania.

Grycman M., 2015, Sprawdź, jak się porozumiewam. Ocena efektywności porozumiewania się dzieci ze złożonymi zaburzeniami komunikacji wraz z propozycjami strategii terapeutycznych, Kwidzyn: Wydawnictwo Rehabilitacyjne Centrum Rozwoju Porozumiewania.

Grzegorczykowa R., 2007, Wstęp do językoznawstwa, Warszawa: Wydawnictwo Naukowe PWN.

Michalik M., 2018, Lingwistyczno-logopedyczne podstawy komunikacji alternatywnej i wspomagającej. Ujęcie metodologiczne, Kraków: Wydawnictwo Naukowe Uniwersytetu Pedagogicznego.

Michalik M., Przebinda E., 2018, Budowanie kompetencji lingwistycznej u osób niemówiących z wykorzystaniem strategii komunikacji alternatywnej, [in:] A. Domagała, U. Mirecka (eds.), 
Metody terapii logopedycznej, Lublin: Wydawnictwo Uniwersytetu Marii Curie-Skłodowskiej, pp. 143-183.

Przebinda E., Michalik M., 2020, Inter- i transdyscyplinarność w opisie niemowności oraz niemówienia [in print].

Rittel T., 1994, Podstawy lingwistyki edukacyjnej. Nabywanie i kształcenie języka, Kraków: Wydawnictwo Naukowe Wyższej Szkoły Pedagogicznej.

Rittel T., Rittel S.J., 2015, Dyskurs edukacyjny. Zagadnienia - znaczenia - terminy. Wybór i opracowanie, Kraków: Collegium Columbinum.

Rocławska-Daniluk M., 2017, Czytanie i pisanie: metodyka zajęć korekcyjno-wyrównawczych, Gdańsk: Wydawnictwo Uniwersytetu Gdańskiego.

Rocławski B., 2010, Podstawy wiedzy o języku polskim dla glottodydaktyków, pedagogów, psychologów i logopedów, Gdańsk: Glottispol.

Tetzchner S., Martinsen H., 2002, Wprowadzenie do wspomagających i alternatywnych sposobów porozumiewania się, Warszawa: Stowarzyszenie „Mówić bez słów”.

\section{Abstract}

The paper identifies and defines augmentative and alternative communication, a new subdiscipline in applied linguistics whose primary parametre is linguistic competence whereas the secondary parameter is the phenomenon of speech inability and speech non-occurrence. At the same time it has been proven that linguistics of augmentative and alternative communication conducts primary, applied and implementation research having a hierarchical layout of scientific aims. It also enables to conduct a logopaedic analysis of mute and nonspeaking persons. The postulates that govern it are presented in the last part of the text.

\section{Streszczenie}

W artykule wyodrębniono i zdefiniowano lingwistykę komunikacji alternatywnej i wspomagającej - nową subdyscyplinę w ramach lingwistyki stosowanej. Jej głównym parametrem jest kompetencja lingwistyczna, a parametrem pomocniczym zjawiska niemowności i niemówienia. Udowodniono jednocześnie, że lingwistyka komunikacji alternatywnej i wspomagającej, mając hierarchiczny układ celów naukowych, prowadzi badania podstawowe, stosowane oraz wdrożeniowe. Umożliwia również diagnozę o charakterze logopedycznym osób niemownych i niemówiących. Postulaty nią rządzące zaprezentowano w ostatniej partii tekstu. 